\title{
Between dreams and reality: Migration of brazilian women to Switzerland*
}

\author{
ENTRE O SONHO E A REALIDADE: MIGRAÇÃO DE BRASILEIRAS PARA A SUÍÇA
}

ENTRE EL SUEÑO Y LA REALIDAD: LA MIGRACIÓN DE BRASILEÑAS A SUIZA

\author{
Flávia de Maria Gomes Schuler ${ }^{1}$, Cristina Maria de Souza Brito Dias ${ }^{2}$
}

\begin{abstract}
The general objective of this article was to study the process of illegal migration of Brazilian women to Switzerland and, more specifically, to analyze the motivations for migration, the difficulties found upon arrival, the circumstances that led them to get married and lastly an evaluation of the whole experience. The methodology was based in a qualitative approach. The participants were eight Brazilian women that illegally migrated to Switzerland but now are married with Swiss or European men. They responded to an interview focused in the objectives of the study. The appreciation of the data was realized with Minayo's Content Analysis. The motivations were related to a bettering of the financial situation. In the difficulties encountered, we can bring out illegality, language and prejudice. Regarding marriage, they married to stay legally in the country. Finally, the evaluation of the experience was negative for most participants.
\end{abstract}

\section{DESCRIPTORS}

Migrants

Women

Marriage

\section{RESUMO}

O objetivo geral deste artigo foi estudar como se deu o processo de migração ilegal de mulheres brasileiras para a Suiça e, mais especificamente, analisar as motivações para a migração, as dificuldades enfrentadas ao chegar, as circunstâncias que as levaram a se casar e uma avaliação da experiência. A metodologia foi baseada em uma abordagem qualitativa. Os participantes foram oito mulheres brasileiras que migraram ilegalmente para a Suíça e atualmente são casadas com suíços ou europeus. Elas responderam a uma entrevista com foco nos objetivos da pesquisa. A apreciação dos dados foi realizada a partir da Análise de Conteúdo Minayo. As motivações foram relacionadas a uma melhorar da situação financeira. Quanto às dificuldades encontradas, podemos destacar a ilegalidade, dificuldades com a língua e os preconceitos enfrentados. Quanto ao casamento, elas se casaram para permanecer no país legalmente. Finalmente, a avaliação da experiência foi para a maioria das participantes negativa.

\section{DESCRITORES \\ Migrantes \\ Mulheres \\ Casamento}

\section{RESUMEN}

El propósito de este trabajo era estudiar el proceso de la migración ilegal de mujeres brasileñas a Suiza, más específicamente, analizar las motivaciones de la migración, las dificultades encontradas a la llegada, las circunstancias que los llevaron a casarse y una revisión de la experiencia. La metodología se basa en un enfoque cualitativo. Los participantes fueron ocho mujeres brasileñas que emigraron ilegalmente a Suiza, pero en la actualidad están casadas con hombres suizos o europeos. Han respondido a una entrevista que se centra en los objetivos del estudio. La evaluación de los datos se realizó con el Análisis de Contenido de Minayo. Las motivaciones fueron relacionadas con una mejor situación financiera. En las dificultades, podemos destacar la ilegalidad, el idioma y los prejuicios enfrentados. Cuanto a la boda, se casaron a permanecer en el país legalmente. La evaluación de la experiencia fue negativa para la mayoría de los participantes.

\section{DESCRIPTORES \\ Migrantes \\ Mujeres \\ Matrimonio}

\footnotetext{
"This article is an excerpt from the Master's Thesis in Clinical Psychology: Intercultural Marriage and its peculiarities: A study of Brazilian women living in Switzerland. Catholic University of Pernambuco. 2010. ${ }^{1}$ Master in Psychology and Doctoral student. Universidade Católica de Pernambuco, Recife, Brazil. ${ }^{2}$ PhD in Clinical Psychology. Universidade Católica de Pernambuco, Recife, Brazil.
}

$\begin{array}{ll}\text { Rev Esc Enferm USP } & \text { Received: } 30 / 04 / 2014 \\ \text { 2014; 48(Esp2):24-30 } & \text { Approved: 16/07/2014 }\end{array}$




\section{INTRODUCTION}

Globalization may be considered one of the most prominent characteristics of the times we live in. In a globalized world, communications go beyond all the expected limits, supported as they are by advanced technology. The Internet allows us to be connected to the world, one mouse click away. Migration between countries, regions, and continents grows daily. In an ever more integrated world, people migrate seeking opportunities on foreign soil that are not available in their own countries. This traffic around the world is enormous - airports suffer the most and are already unable to deal with such intense air traffic. Even diseases, which used to be specific to given areas of the world, are found everywhere, given people's enormous mobility.

Amazonas, Dias, and Santos ${ }^{(1)}$ state that, after the onset of globalization, geographical distance is no longer an impediment to the development of affective ties. They state further that, among all the changes that the process of globalization is causing, those in sexuality, in affective relationships, in marriages and in families themselves are the ones with the greatest impact on people's lives. As a consequence of globalization, we see nowadays that intercultural families make up a great part of the European population, as well as the world's ${ }^{(2)}$. The main objective of this research project was to study the process of illegal migration of Brazilian women to Switzerland and, more specifically, to analyze the motivations for migration, the difficulties found upon arrival in the new country, the circumstances that led them to get married, and lastly an evaluation of the whole experience.

\section{Female migration}

There is a current phenomenon known as the "feminization of migration," which stands in stark contrast with the beginnings of Brazilian emigration. Generally speaking, the family remained in Brazilian national territory while the father traveled abroad in order to support his family. At that point in time, the exit flows of the Brazilian populace were a fairly new process, unknown until then even by the emigrant society, and had not yet been going on long enough to make in-depth study of the dynamics of these events possible ${ }^{(3)}$. Such movements were perceived as largely temporary impulses, carried out mostly by men. As the years went by, however, and especially with the development of larger and broader social support networks for these migrations, the presence of women intensified, finally assuming the prominent role within these flows, in an attempt to realize expectations of social mobility and ascension. This change, which is reflected in the data, also coincides with recent analyses of changes in the pattern of intent in relation to time spent overseas. Currently, according to the United Nations Report on the Division of Population ${ }^{(4)}$, of the 191 million migrants around the world, 94.5 million are women who left their countries in search of better opportunities. It further points out that today, in many countries, women represent the majority of immigrants, especially in North America, Europe, the Middle East, and Oceania. Women also represent, in various countries, the majority of emigrants, particularly in Asia and Latin America. In Brazil this fact has been confirmed - according to the Census of the Brazilian Institute of Geography and Statistics ${ }^{(5)}$, woman are the majority among those who emigrated (53.8\%). In the states in the northeast, the percentage of women emigrants is even greater, making up $64.3 \%$ in Pernambuco, $70.1 \%$ in Ceará, and $70.3 \%$ in Rio Grande do Norte.

Brazilians leave their home country no longer on a temporary basis, but with the expectation to remain on foreign soil as long as possible, or even definitively. We cite as an example the data collected by journalist Mônica Fauss in Weller ${ }^{(6)}$. According to this author, $70 \%$ of Brazilians living in Germany are women, which leads us to conclude that the women are looking for new opportunities. When there are many obstacles, expectations of improvement in living conditions practically do not exist. When they are attracted by the tourism industry and the trafficking of women, emigration to a first world country begins to be seen as an alternative for many women who leave the country with the responsibility of not only guaranteeing their own survival, but also that of their family members.

According to Weller ${ }^{(6)}$, many women arrived in Germany via relationships with tourists who came to Brazil. Although female immigration is largely associated to sexual exploitation, this is not the only and may not be the main motive behind the phenomenon of "feminization of migrations." With the growing number of women in higher education, as well as in the professional market, in the last decades, the number of female migrants who left their country in order to increase their professional qualifications, or for mere curiosity, to get to know other countries, cultures, and ways of life, has increased. What was often first thought of as a project of a few months or years becomes a permanent move to another country, often associated to marriage and building a family.

The situation is no different in Switzerland. The Brazilian consul in Zurich, Vitoria Cleaver ${ }^{(7)}$, states, the absolute majority of Brazilians in Switzerland, almost 60,000 according to the embassy, are women. They show up in second place on the list of women the Swiss prefer to marry. Let us not forget that, according to Hoffmann ${ }^{(8)}$, Switzerland has the seventh largest Brazilian community in Europe, behind only the U.K., Portugal, Spain, Germany, Italy, and France.

\section{Brazilians in Switzerland}

In Switzerland, Brazilians were, along with Dominicans, Moroccans, and Thais, the largest group of migrant women from the so-called "third world" or "developing countries." It is difficult to talk about exact numbers, since a large percentage of them live illegally in the country, with 
no registry in any official organ ${ }^{(9)}$. Brazil's Ministry of Foreign Relations ${ }^{(10)}$ estimates that around 60.000 Brazilians currently live in Switzerland. This number is calculated according to the number of consular services and does not distinguish the official state of the inhabitants. According to Switzerland's Federal Department of Statistics ${ }^{(11)}$, 14.108 Brazilians live in the country. The discrepancy in the information from the two countries demonstrates just how many Brazilians live illegally in Switzerland. Since it gets more difficult to legally emigrate to Switzerland daily, the possibilities are now restricted to working as dancers, through marriage, or as tourists. To work as a dancer, a woman needs an artist's visa, valid for eight months, which she can acquire at the Swiss consulate presenting three contracts with nightclub owners. According to Huber $^{(9)}$, upon leaving Brazil, due to contracts made with middlemen, passport costs and travel expenses, most women are already in debt. According to Zurich's Center for Female Immigration ${ }^{(12)}$, $90 \%$ of dancers also work as prostitutes. They submit themselves to discrimination, humiliation, injustice, and violence on the part of the nightclub owners.

The women who migrate as tourists seek, during their first months in the country, both a husband as well as a job in the parallel market. According to Baeckert ${ }^{(13)}$, they arrive with few resources and lots of dreams, among these to marry a Swiss man or return to Brazil with the means to build their own house. Thus thousands of Brazilian women go to try their luck as nannies or maids. They enter as tourists and remain thus for years, until they arrange a marriage or the financial independence they dreamt of for their family in Brazil. With this purpose, many of them leave their families and children to seek a better life.

A life lived illegally is generally filled with fears, needs, and a great psychological burden ${ }^{(12)}$. Access to medical treatment is limited, if not inexistent, similar to other situations that require identification. The women are generally exploited because they have no workers' rights and they must always count on the possibility of being fired. The fear of being caught by the police is ever present, and can result in deportation, a fine, or jail time. When these illegal women are discovered, they are guilty of illegal entry, permanence, and work in the country, unless they are recognized as victims of the international trafficking of women. If it becomes clear that this is the case, they are deported to their country of origin and must return to their precarious life conditions: they go right back to the place they were running away from. Thus, the help that they sent their family members ceases overnight, which often means that their children have to stop studying, and many families even lose the houses they lived in because they no longer receive the aid sent by these women. This situation is so difficult that a majority of these women opts for marriage as a solution to stay in the country ${ }^{(12)}$.

The married Brazilian women living in Switzerland can be divided, basically, into two groups: those who meet their future husbands in Brazil and migrate to Switzerland, since Brazil is an important tourist destination, attracting tourists that want to get to know the "exotic tropics"; and the women who decide to migrate on their own, in the beginning as dancers or tourists, seeking work and marriage, to build or rebuild a family. Many Brazilian women migrate to Switzerland with dreams of finding their "prince charming" and, apart from the huge culture shock, some of them, unfortunately, are faced with marriages of subservience and financial dependence, as well as confinement to the home and the prohibition of working outside the home ${ }^{(14)}$. We would like to point out and remain alert to the fact that, in reality, migration to any country should take into account not only the positive factors, but also the negatives and difficulties to be faced.

\section{METHODOLOGY}

This research used a qualitative methodology. As to the criteria for selection of the participants, we used a purposeful sample ${ }^{(15)}$. The eight participants in our study were Brazilian women who migrated illegally to Switzerland and are now married to Swiss or European men, living in the cantons of Basel, Zürich, or Aargau. The interviewees come from various Brazilian states, are aged 28 to 51 , have been married an average of seven years, and all of whom have children in Switzerland or Brazil. Their schooling goes from elementary to high school.

The interviews were all carried out in Switzerland in 2010. Before we began each interview, the purposes of the research were explained to each participant, and they were presented with the Term of Free and Informed Consent, which guarantees anonymity. After reading and signing the term, we began the interview. The interview script was approved by the Ethics Committee. The interviews were carried out individually, recorded and later transcribed. We followed Minayo's ${ }^{(16)}$ guidance about anonymity; therefore, all the participants have had their names changed. The interviews were analyzed according to Content Analysis guidelines, which consists of three phases: pre-analysis, organization of the corpus,_analysis and interpretation of the material obtained.

\section{ANALYSIS AND DISCUSSION OF RESULTS}

In this section we will present and discuss the results found in the interviews carried out with the eight Brazilian women, according to four categories:

\section{A. Motivation for migration}

On this topic, the participants indicated as the main causes for migration the desire for better living conditions, better work, the dream of owning their own house and of a possible marriage so they could remain in the country and bring their children - in short, migration meant a new beginning in their lives.
Between dreams and reality: Migration of brazilian women to Switzerland Schuler FMG, Dias CMSB 
"I already had two children and had been abandoned. Many friends of mine had come here and gotten married. That's why I came. There were even many Brazilians here from the street I lived on who had met someone and gotten married. I thought: I'm gonna meet my prince charming." (Rebeca)

'My parents' situation was really tough. So my mother told my aunt who already lived here, 'The greatest help you can give me is take my daughter to Switzerland.' So I came to work here and help my parents." (Gil)

According to Garcia ${ }^{(17)}$, if the experience of migration is one of tearing apart, it is also, at the same time, the promise of the brand new: opportunities, possibilities, the construction of a future without mediation from the past. Living as a foreigner is a multifaceted experience. The way each individual perceives herself in this condition contributes to the success of the emigration, or its failure and, consequently, the individual's return. But why did they emigrate? Why do they put themselves in the condition of eternal strangers in a world that doesn't belong to them and does not welcome them? The experiences narrated by the Brazilian women who emigrated suggest an atypical situation of exile. Many of them could be classified as fugitives from unemployment, poverty, or lack of opportunities. These opportunities are unequally distributed in Brazil, which affects survival, leading to the search for greater opportunities for employment and income.

\section{B. Challenges faced in the cultural context}

In this item, the participants' speeches pointed out as the main challenges faced the language, loneliness, missing home, illegality, leaving their children, the Swiss mentality, and prejudice.

According to Daure and Coulon ${ }^{(18)}$, for the migrant, arrival in the new country marks the beginning of her interactions with the new culture and population. This is, without a doubt, the longest stage of migration, and for some people it will never end; that is, the feeling of being constantly in contact with the foreign, with the strange, with the unfamiliar can last one's whole life in the new country.

Souza ${ }^{(19)}$ states that, even when these women's living conditions improve from one viewpoint, there will always be culture shock and a difficult process of adaptation, so it is important to study the conditions for integration into the target country. The difficulties faced by these women are innumerable. According to Scheifele ${ }^{(20)}$, in migration, even when people's motives, as well as destinations, are different, there are always similarities. According to Pereira ${ }^{(21)}$, one of the greatest challenges is the language. Many people feel almost like a child, because they have to learn everything again.

"When I arrived here, the most difficult things were the language and living illegally. I had no real interest in learning the language. I just wanted to make some money and go back, but if we're here we've got to learn at least a little bit, so I got serious and I learned, but I still have a lot of trouble. I have to keep studying." (Carolina)

"The language is the most complicated l've ever heard and that's why I didn't want to stay here, but since my mother was sick, I had to work to send her money. I would leave the house and come back in complete silence. I missed everything I had there [in Brazil] and didn't have here [in Switzerland]. That was the hardest part." (Lilian)

With migration, there may be a reduction in individual competence, because they feel incapable of carrying out daily tasks. They enter a process of dependency, because they don't know how to speak and don't even know the rules of social behavior. According to Figueiredo ${ }^{(22)}$, the need to communicate emerges from social interactions. Being capable of dealing with social needs implies being socially able. The lack of the language or the low level at which the country's language is spoken can easily lead to isolation and loneliness. Souza ${ }^{(19)}$ states that one of the biggest problems of the migrant women may be loneliness, including the loneliness of married women, as can be seen in the following speech:

\section{"The greatest impact I felt when I arrived here was loneli- ness. I lived in the little town of Dorf. I never saw anybody. On TV I couldn't understand a thing. I missed home and felt alone. I spent all week without hearing a thing, not a sound. Even the annoying music from the neighbor in Bra- zil would be better than total silence." (Suelen)}

According to Weiss ${ }^{(23)}$, migration may open up new possibilities, new directions, and new uses of other economic and social resources, but it is always accompanied by stress. The experience of migration is experienced as burdensome and generates a lot of insecurity. Another difficulty these participants experience on a daily basis is illegality since, even when these women are within the three months of permanence allowed in Switzerland, once they begin working they become illegal, since this is not permitted to tourists. According to Weller ${ }^{(6)}$, one of the greatest problems of living clandestinely is the constant fear of being discovered and the consequences of this. In this sense, "paperless" migrants are forced to develop a series of strategies and mechanisms to maintain the status of someone who officially does not exist and does not live in the country. They are obliged, for instance, to avoid places which may, perchance, be monitored by the police, to dress in a way that does not draw attention, and they can never enter a bus, trolley, or train without purchasing a ticket. The following quotes serve as examples:

"When I arrived, there were a lot of difficulties. I came with a suitcase full of dreams, but working without papers and without speaking German is very hard. Reality soon hit hard." (Rebeca)

"Living here illegally is the most difficult. I was afraid of being caught by the police on the buses, the trains, in the streets, and not being able to go back to Brazil, because if I left Switzerland I wouldn't be allowed back." (Amélia) 
Illegality makes it impossible to get a job in the formal market and the need to remain "invisible" makes many of these women seek jobs as maids or nannies, since these places of work will rarely suffer police raids. These interviewees, soon after arrival in Switzerland, worked in family houses as cleaning ladies or nannies, one of them as a dancer and another as a prostitute, as we can see in the following quotes:

"I was living illegally, I had to work to send money to my dad to raise my kids, so I did that (prostitution) in a moment of weakness, I got involved, but at that moment I had no other solution." (Bernadete)

"In my hometown I was a seamstress; I had my profession. Here I had to become a cleaning lady. It's hard to get anything else when you're illegal and don't speak the language. Some people thought I came here to prostitute myself, but I never did that." (Amélia)

For those who have children, leaving them in Brazil, generally with grandparents or aunts and uncles, is a difficulty that generally leads to a lot of sadness, as seen in the quote below:

"I worked to send money to my children, who I had left in Brazil with my mother. They suffered a lot and couldn't understand. Daily life was very hard." (Rebeca)

Prejudice is another difficulty found by the Brazilians in Switzerland, due to the fact that they are foreigners. This is aggravated by the stereotype of Brazilian women. Unfortunately, the image the Swiss have of Brazilians, especially the women, is well known. Pereira ${ }^{(24)}$ states that the image of Brazilian women is communicated in a very lewd manner. One has only to look at travel catalogs to see how we were (or still are) represented, and the increase of sexual tourism to Brazil is evidence of this. We see that all these difficulties are experienced daily, as the following excerpts from the interviews show:

"There's a lot of prejudice against Brazilian women, with the stereotype of the 'mulata' and the beautiful women, so the Swiss think all Brazilian women are like that." (Lilian)

The Swiss mentality is often cited as one of the difficulties, because culturally Brazilians and the Swiss are very different. These are exactly the differences the Brazilian women pointed out:

"When I arrived at my aunt's house, it was really tough. She already lived here with her son and I came to take care of my nephew so she could go to work. It was impossible to get along with her husband! He was very Swiss. Everything has to always be the same, like a diagram, nothing can change. I was sad all the time, I couldn't get used to that, but I had to help my family." (Gil)

\section{Circumstances in which they got married}

All the interviewees, after a given period in Switzerland, for different reasons, such as wanting to remain in
Switzerland, get out of their illegal situation, or bring their children who were still in Brazil, ended up opting for a marriage that was not, in principle, based on love, as can be seen in the following quotes:

“I don't want to go back to Brazil to have no job, while here everything looks so nice and organized. So I thought: to stay here I have to get married. Getting married here is easy. Europeans like Latinas. Within six months I had gotten married and separated, because I discovered my husband was a drug dealer. Then I met my second husband in a disco, I got pregnant so he had to marry me." (Renata)

"My aunt's husband's friend told my aunt he liked me - he couldn't tell me because I spoke very little German. When I met him, I didn't like him. But he asked, 'Do you want to stay in Switzerland? So stay with me, we'll get married, and we'll let time tell."' (Gil)

"I was living illegally and I had to work and send money to my dad to raise my kids. My sister always told me, 'You've got to get married! You've got to get married!' So I met my husband in a nightclub and I lived with him for three months. Then I went to Brazil and came back with my kids and married him." (Bernadete)

All of them were unemployed in Brazil, with families or children who depended on them, which certainly led them to think not only of themselves, but of their families and children, since marriage makes their situation in the country official and gives those who have children the opportunity to bring them. Janka and Athole ${ }^{(24)}$ claim that the visa given to migrant women clearly states that marriage is the only justification for their stay in Switzerland. We must point out that we do not mean to say that love cannot develop during the marriage. However, at the beginning, the marriage is based on other motives. We see this confirmed in the following testimony:

"Actually, I didn't get married because I was in love; I got married to stay here. Today my marriage is good, but we went through many difficulties to grow together" (Carolina)

\section{Evaluation of the experience}

In general, the participants' evaluation was largely negative when they referred to the illusion of finding their "prince charming" and get rich, and finding themselves unprepared for a demanding labor market and to dominate a difficult language and live in a different country.

\begin{abstract}
"When someone comes to Switzerland they think it's all smooth sailing, but it's not. If I knew what it was really like here, I wouldn't have come here, I would have stayed in Brazil, studied, taken a course, done anything, but I wouldn't have come because I suffered a lot. Actually, it was everything but what I dreamed of!" (Gil)
\end{abstract}

"I hope that today, with the technology and the news, people know that this is a novel thought. Maybe that was my problem. An European Paradise does not exist. Europa is not what we think. The women need clarification not wrong
Between dreams and reality: Migration of brazilian women to Switzerland Schuler FMG, Dias CMSB 
to dream. It is another reality; is a shock, another culture.

My dream is to go back, but I don't know if I will." (Lilian)

Pereira ${ }^{(21)}$ wrote about the admiration that people in Brazil have about those who live in Switzerland, thinking that they have everything by living in a rich country, but do not know of unpleasant situations they face, which are often kept in secret by women themselves. For the author, this is linked to the illusion that Europe is a paradise.

\section{FINAL CONSIDERATIONS}

Globalization and new forms of technology, as well as changes in the social roles of women, have contributed to the increase in female migration and, consequently, intercultural marriages. However, we observe that these women, upon migration, as a rule, were not aware of the difficulties they would face leaving their home country. What seems to have been very clear to these women are the benefits they would have leaving Brazil, since many of them migrated based on the dream of finding their "prince charming", thinking they would live "happily ever after," like in a fairy tale. The reality of daily life, however, proved to be very different.

The motives for female migration are many: unemployment, lack of financial conditions, and reconstruction of a family. The results show that most of the Brazilian women who migrated to Switzerland illegally are faced with strict migration laws and end up getting married to stay in Switzerland, instead of dealing with the lack of opportunities if they were to return to Brazil. At the same time, it is a fact that many of them felt pressured into marriage because they had left children in Brazil and wanted to bring them to live with them, or they had family members in Brazil they felt they needed to help. Furthermore, we found that, whatever the motives, the challenges the Brazilian women faced to adapt were innumerable, with the language being mentioned by all the research participants as one of the greatest difficulties, among others. In other words, what they expected from migration, everything they idealized, for the most part ended up not coming true.

Given the complexity of this topic, especially in regards to the different motives for migration, it would be tremendously pretentious to believe we have learned everything there is to learn. We consider, however, that we were able to make an initial survey of the issue, but certainly new investigations are necessary. However, we believe we have contributed especially to sensitize professionals and families to the problems related to migration, hoping, furthermore, to bring awareness, to those women who migrate to work, about the reality of migration and its consequences.

\section{REFERENCES}

1. Amazonas MC, Dias CMS, Santos G. Conjugalidades interculturais e relações de gênero. In: Osório LC, Pascual, VME, organizadores. Manual de Terapia Familiar. São Paulo: Artmed Editora; 2009. p.74-87.

2. Centrum für Binationale und Interkulturelle Paare und Familien [Internet]. Services,1999[citado 2009 maio 10]. Available from http:// www.cbif.at/frame chtml

3. Oliveira AC. Mulheres Imigrantes no Sul da Flórida: Um estudo de caso revelando diferenças [Internet]. 2006 [citado 2009 ago.23]. Available from http://www.fazendogenero.ufsc.br/7/ artigos/A/Adriana Capuano Oliveira 55.pdf

4. United Nations Population Fund - UNFPA. Gender iquality [Internet], 2007 [cited 2010 set.10]. Available from: hptt:// www. unfpa.org/public/

5. IBGE. Instituto Brasileiro de Geografia e Estatística - Censo Demográfico 2010. 2011. [cited 2011 nov.09]. Available from: http://www.ibge.gov.br/home/estatisticas/população

6. Weller W. Entrevista. Revista Scalabriniane nel Mondo. Ano 12 n.22, Brasília: CSEM,2004.

7. Cleaver V. Ninguém pode Integrar outra pessoa. [Internet]. 2009 [cited 2010 abr.24] . Available from: http//www.swissinfo.ch/por/sociedad

8. Hoffmann G. Brasileiras em segundo lugar na preferência dos suíços, 2009. [cited 2010 jul.05]. Available from http:// www. swissinfo.ch/reportagens/ brasileiras...

9. Huber L. Nos trajetos da sujeição: brasileiras na Suíça. Travessia - Revista do Migrante. 1996; (26):35-37.

10. Ministério das Relações Exteriores - MRE. Notícias para o Mundo. [Internet]. 2009 [cited 2010 jun. 06]. Available from: http://www.swissinfo.ch.sociedade/Emigrantes

11. Bundesamt für Statistik -BFS. In: Binational (Preliminary Remarks). 2007. [cited 2009 nov.11]. Available from: http:// www.binational.ch/en/fragen/vorbemerkung.html

12. Fachstelle Frauenhandel und Frauenmigration .Beratung für migrantinnen. [Internet]. 2009 [cited 2010 abr. 24. Available from: http://www.fiz-info.ch/index.php?page 483

13. Baeckert LT. Os sonhos das babás brasileiras ilegais na Suíça. [Internte]. 2008 [cited 2010 mai.06]. Available from http:// babas brasileiras

14. Ammann SB, Ammann P. Por que os migrantes brasileiros escolhem a Suíça como destino? [Internet]. 2006 [cited 2010 mai. 06]. Available from: http://www.swissinfo.ch/por/especiais/cronicas do estrangeiro/por que os emigrantes 
15. Turato ER. Tratado da metodologia da pesquisa clínico-qualitativa. Petrópolis: Vozes; 2003.

16. Minayo MC. O desafio do conhecimento: pesquisa qualitativa em saúde. São Paulo: Hucite; 2004.

17. Garcia L. Mulheres transnacionais. Imaginário. USP; 2007 (13):379-398.

18. Daure I, Reveyrand-Coulon O. Transmissão cultural entre pais e filhos: uma das chaves do processo de migração. [Internte]. 2009 [cited 2010 abr.10]. Available from: http://www.scielo.br/scielo. php?pid=S0103-56652009000200011\&script=sci_arttext

19. Souza ICF. A integração de imigrantes brasileiras em Roma: conquistas e dificuldades. Imaginário. USP, 2007 (13):399-415.

20. Scheifele S. Migration und Psyche:erschutterung und Aufbruch. Gissen, Alemanha: Psychosozial, 2008.
21. Pereira C. Migração: história, aspectos legais e situação das migrantes na Suíça. In: I Encontro Nacional de Brasileiras na Suíça. ( documentação final); Berna; 1998. [citado 2010 mai.20]. Disponível em: http://www. encontro-brasileiro.ch

22. Figueiredo PMV. A influência do lócus de controle conjugal nas habilidades sociais e na satisfação do casamento. [Internet]. 2005. [cited 2010 mai.20]. Available from: http://ciênciaecogniçao.org

23. Weiss R. Macht Migration Krank? Eine transdizciplinäre Analyse der Gesundheit von Migrantinen und Migrant. Zurique, Suíça: Seismo; 2005.

24. Janka V, Athoele A. Estrangeiras sonham amor alpino [Internet]. 2003 [cited 2010 set. 27]. Available from: http:// www. swissinfo.ch/ por/índex/estrangeiras_sonham_amor_alpino_(I) 